DOI: 10.34015/2523-4552.2020.1.14

УдК 340.113

Драч Д. Л., здобувач вищої освіти ступеня «Бакалавр» Донецького національного університету імені Василя Стуса ORCID: 0000-0002-9111-2694

\title{
МЕТАПРАВО: ПРОБЛЕМИ РОЗУМІННЯ ТА ЗНАЧЕННЯ ДЛЯ ЮРИДИЧНОЇ НАУКИ І ПРАКТИКИ
}

Статтю присвячено дослідженню проблем розуміння та значення метаправа для юридичної науки і практики. Визначено поняття метаправа як юридико-лінгвістичної категорії. 3'ясовано сутність досліджуваного явища на основі аналізу наукових підходів до його розуміння, концепції співвідношення метаправа $з$ юридичною технікою та семіотикою права. Розкрито зміст особливостей метаправа, які характеризують його сутність. Прослідковано фрагментарні аспекти значення метаправа та інтегровано їх забезпеченням ефективності механізму правового регулювання.

Ключові слова: метаправо; юридична техніка; юридична мова; нормативно-правовий акт; юридичний документ; правове регулювання.

Статья посвящена исследованию проблем понимания и значения метаправа для юридической науки и практики. Определено понятие метаправа как юридико-лингвистической категории. Выявлено сущность исследуемого явления на основании анализа научных подходов к его пониманию, концепции соотношения метаправа с юридической техникой и семиотикой права. Раскрыто содержание особенностей метаправа, которые характеризируют его сущность. Рассмотрены фрагментарные аспекты значения метаправа и интегрировано их обеспечением эффективности механизма правового регулирования.

Ключевые слова: метаправо; юридическая техника; нормативноправовой акт; юридический документ; правовое регулирование.

Постановка проблеми. Юридична термінологія $\epsilon$ елементом змістовного аспекту структури закону, що $є$ не лише формальним виразником законодавчих приписів, але й чинником їх якісного впровадження в правову реальність. Незважаючи на безпрецедентне значення вищевказаного явища, його проблематика не $\epsilon$ вичерпною. Так, розуміння сутності метаправа не $\epsilon$ однозначним, а його співвідношення з юридичною технікою та семіотикою права потребує додаткового аналізу. Застаріле ж законодавче регулювання застосування юридичної термінології вимагає оновлення цих приписів.

Аналіз останніх досліджень i публікацій. Дослідженню метаправа присвятили свої роботи О.В. Волошенюк, Н. В. Артикуца, Н. О. Горобець, М. І. Клеандров, А. М. Кучук, В. К. Самігулін, С. С. Сливка та інші. 
Однак у цій сфері постійно з'являються нові тенденції, зумовлені стрімким розвитком суспільства, держави і права. Крім того, відповідність законодавства нормативно встановленим вимогам і потребам суспільства $є$ певною гарантією ефективного правового впливу, а отже, i правопорядку в суспільстві та державі, що і вказує на актуальність цієї теми.

Постановка завдання. Мета дослідження полягає у з'ясуванні поняття та сутності метаправа, формулюванні концепцій співвідношення юридичної термінології 3 юридичною технікою та семіотикою права, а також розкритті особливостей метаправа та його значення.

Виклад основного матеріалу. Метаправо як техніко-юридичний засіб представляє собою важливий елемент правотворчого й правореалізаційного процесів, адже воно має значний вплив на змістову сутніть нормативно-правового акту, а також в контексті тлумачення права виступає основним його об'єктом. Аналіз багатьох досліджень метаправа зумовлює можливість виділення певних підходів, основними серед яких $є$ його розуміння як: 1) складової юридичної техніки; 2) правового засобу, інтегрованого 3 інформаційними технологіями; 3) елементу правової системи; 4) всепланетного права; 5) міжцивілізаційного явища. Синтез цих підходів виражає сутність метаправа.

Розуміння метаправа як складової юридичної техніки обгрунтовував, зокрема, М. І. Козюбра, який визнає його як «сукупність різноманітних термінів, які використовуються в текстах юридичних документів (правових актів)», що сприяє «вираженню юридичної думки і юридичної реальності» завдяки застосуванню метаправа як інструмента юридичної мови [1, c. 204, 217]. Така характеристика метаправа відображає його фактичну сутність та основне призначення, виражаючи його архітектоніку сукупністю композиційно-стилістичних засобів.

Дійсно, юридична термінологія $\epsilon$ змістовим наповненням, а отже, i частиною структури правових актів, що завдяки юридико-лінгвістичному формулюванню вимог правового регулювання допомагає відобразити предмет, метод, спосіб і напрямок конкретного праворегулятивного впливу. До того ж, такий підхід характеризує сутність метаправа у найбільш чіткому i лаконічному значенні, що сприяє розумінню його основного змісту. Також метаправо визнається важливим юридикотехнічним засобом на етапах нормотворчості, правореалізації, правозастосування і тлумачення права. У той же час, такий підхід викликає певні зауваження, оскільки зосереджує увагу переважно на юридичних термінах як основній складовій метаправа, ігноруючи правила і механізми їх застосування, експертизи, тлумачення тощо. Варто зазначити, що сутність метаправа в межах цього підходу $\epsilon$ більш складною, адже вона поєднує всі суміжні аспекти, пов'язані із впровадженнням і функціонуванням юридичної термінології.

Зважаючи на те, що метаправо $\epsilon$, перш за все, елементом юридичної техніки, доцільно також з'ясувати їх співвідношення. Зазвичай до структури юридичної техніки включають юридичні терміни, конструкції, пре- 
зумпції та фікції. Система всіх юридичних термінів складає метаправо, однак до нього не входять суміжні елементи - юридичні конструкції, оскільки вони представляють собою на порядок вищу категорію, яка формується завдяки об'єднанню взаємопов'язаних юридичних термінів у єдину модель правових процесів та явищ на основі узагальнення їх структурно-змістового наповнення. Юридичні презумпції та фікції набувають своєї значеннєвої суті та мовно-юридичного вираження завдяки абстрагуванню попередніх елементів юридичної техніки. У свою чергу, поєднання всіх елементів юридичної техніки дозволяє конструювати юридичні фрази, сукупність яких складає юридичну мову. Юридична мова $\epsilon$ важливим елементом юридичної техніки нормотворчості, яка $\epsilon$ різновидом юридичної техніки. Загалом метаправо $€$ значною частиною саме юридичної техніки нормотворчості і також взаємодіє з інтерпретаційною,

правореалізаційною та правозастосовною юридичною технікою на умовах з'ясування й впровадження змісту законодавчих положень. Зовсім інший характер взаємодії метаправа із видом юридичної техніки, що пов'язаний із систематизацією та обліком нормативноправових актів, адже метаправо за рахунок визначення змісту останніх дозволяє упорядкувати їх зовнішню та внутрішню структуру, а також на основі цього належно їх архівувати. Звідси випливає, що метаправо $є$ не лише частиною юридичної техніки, а й основним іï «механізмом», який $\epsilon$ своєрідною передумовою, певним фундаментом для існування інших її елементів, хоч воно і $\epsilon$ найменшою одиницею відносно інших елементів юридичної техніки.

Прояв певних особливостей спостерігається також при співвідношенні метаправа й семіотики права. Остання являє собою «категорію загальної теорії права, яка знаходить своє відображення на межі теорії права, теорії мови і теорії мислення і яка відображає типологію праворозуміння і рівень правової культури конкретного суспільства» [2, с. 35] через сигнали, коди, символи та знаки правової дійсності, що $є$ формами буття права, тобто які $\epsilon$ специфічним способом вираження його сутності [3, с. 39]. Проаналізувавши сутність обох понять та їх найменші одиниці, варто зазначити, що літерні знаки $€$ складовою будь-якого юридичного терміну, тобто семіотика права виступає структурним елементом, а отже, і засобом формування юридичної термінології. До того ж, семіотика права лежить в основі як інших елементів юридичної техніки, так і юридичної мови, а тому семіотику права слід вважати фундаментом такої ознаки права, як його формальної визначеності, яка «матеріалізує» його зміст.

Метаправо прирівнюється до «особливої галузі права прикладного характеру, яка поєднує правовий i технічний аспекти» [4; 5], у роботі Л. Голоскокова. Правовий аспект у межах такого підходу позначає метаправо як засіб юридичної мови, який $є$ однією з передумов вираження змісту норм права через відповідну термінологію. Технічний аспект пов'язує метаправо з інформаційними технологіями, які інтегровані у всі сфери суспільного життя, здійснюючи позитивний вплив на їх розвиток, тобто вони сприяють створенню й 
ефективному функціонуванню юридико-віртуального простору, у межах якого існує електронне врядування, електронні юридичні словники, електронні інформаційні бази даних тощо, зміст яких суттєво становить метаправо. 3 одного боку, такий підхід відображає осучаснення метаправа та його пристосування до нових умов життя і потреб суспільства, що $€$ дійсно важливим. 3 іншого боку, інформатизація метаправа не $\epsilon$ виразником його сутності, адже акцентує увагу на особливостях його розвитку, що зумовлює переважно модернізаційний зміст цього підходу.

Метаправо як елемент правової системи аналізується в багатьох його значеннях. Так, С. С. Сливка розглядає метаправо у філософськоправовому аспекті, виражаючи це поняття у «вищих аксіоматичних правових цінностях, які випливають із надчуттєвих релігійних принципів пізнання людиною світу для гармонійного завершення культури власного розуму, реалізації права на безсмертя» [6, с. 7-8]. Такий підхід відображає сутність метаправа шляхом його ототожнення з правовими принципами, в основі яких лежать найвищі правові цінності, які $\epsilon$ орієнтиром для правового регулювання, зважаючи на важливість техніко-юридичних засобів для його здійснення. Іншої думки дотримується А. М. Кучук, який вважає, що «юридична термінологія $\epsilon$ відображенням світоглядних ідей відповідної правової культури» із врахуванням її особливостей [7, с. 40]. Згідно з цим підходом, метаправо представляє собою змістовне наповнення права не лише як системи нормативно-правових актів, a i як публічного явища із стабілізаційно-інтегруючим призначенням, пов'язане 3 праворозумінням та правовою ментальністю. Обидва аспекти розгляду метаправа як елементу правової системи виражають його функціональне призначення, акцентуючи увагу на фундаментально-правовій та правокультурній природі відповідно, кожна з яких так чи інакше характеризує сутність метаправа. Однак виокремлення таких характеристик базується на факультативних ознаках метаправа - відповідності принципам права та відображенні специфічних рис конкретної правової культури зокрема, тобто метаправо за такого підходу виступає одним 3 показників конкретної правової системи, не виявляючи своєї справжньої сутності.

На характеристиці метаправа як всепланетного права зосереджує увагу В.К. Самігуллін, який стверджує, що воно $\epsilon$ за своєю суттю здебільшого науковим явищем, «правова теорія якого має мовне оформлення, яке діє в масштабі всієї планети і поширює своє значення порівну на міжнародне і внутрішньодержавне (національне) право», тобто це «особлива соціокультурна реальність» [8, с. 76-78] глобального значення. Юридична термінологія виступає своєрідним комплексом мовної символіки, яка повинна мати однакове тлумачення 3 метою забезпечення такого розуміння правових норм, яке буде ефективно відображатися на їхній реалізації незалежно від особи й території тлумачення. Справді, метаправо $€$ універсальним засобом юридичної техніки, який об'єктивно виражає соціально-правову реальність задля належного впливу на правовідно- 
сини, від якого залежить ефективність впровадження права в суспільні відносини. Незважаючи на це, такий підхід викликає певні зауваження, оскільки застосування метаправа не обмежується науковим середовищем, адже воно знаходить свій вияв і в нормотворчій, правореалізаційній та правозастосовній сферах. Тому визнання юридичної термінології як всепланетного права не повною мірою відображає її зміст.

Сутність метаправа як міжцивілізаційного явища виражена в поглядах Е. Дж. Хейлі, який стверджував, що «поширення сфери дії існуючих систем права, 3 їхніми недоліками та ідеологічними обмеженнями, внутрішніми конфліктами й непослідовностями під виглядом «міжнародного права» на «зовнішній простір та небесні тіла», насправді $€$ поширенням наших земних конфліктів і нетерпимості у Всесвіт, що потенційно міг би відкрити для людства нову еру - еру миру, співробітництва та великих успіхів у науці й філософії» [9, с. 394; 10]. Тобто метаправо $\epsilon$ таким засобом юридичної техніки, який сприяє правовому врегулюванню суспільних відносин не лише між людьми, а й між позаземними цивілізаціями, виражаючи найбільш абстрактні юридичні факти та впливаючи на їх перебіг 3 метою забезпечення правопорядку. Звісно, право $\epsilon$ достатньо ефективним і авторитетним засобом упорядкування суспільних відносин завдяки характеристикам його сутності та особливим механізмам його впливу. Однак на даний час відсутні достовірні докази існування позаземних цивілізацій, а також наявна проблема щодо створення такого правового регулю- вання, яке б максимально враховувало інтереси всіх учасників правовідносин міжпланетного масштабу через суттєву різницю рівня культури й умов життя людей та іншопланетих істот, якщо вони таки існують. Тому сьогодні метаправо ще не досягло того рівня розвитку, який би був достатнім для врегулювання міжпланетних відносин; космічне право є відносно новою галуззю, що і зумовлює розуміння такого підходу здебільшого як наукової фантастики. Сутність метаправа конкретизується в його особливостях, до яких належать науковий характер, певні вимоги до його вираження, сприйняття його як вищого рівня правового розвитку та тропологічне тлумачення.

Науковий характер метаправа зумовлюється тим, шо «вказаний термін не $є$ офіційно визнаним, не використовується у правотворчій діяльності та $\epsilon$, скоріше, прикладом метамови» [11, с. 28]. Звісно, застосування метаправа не обмежується науковою сферою, адже основний зміст цього явища становить юридична термінологія, яка поширюється також і на законодавство, і на юридичну практику. Однак саме наука $\epsilon$ каталізатором розвитку юридичної термінології, впроваджуючи нові терміни, вдосконалюючи їх, з'ясовуючи їх зміст.

Як вже зазначалося, сутність метаправа $\epsilon$ складною, адже вона включає не лише юридичну термінологію, а й правила та механізми їі застосування, тлумачення, експертизи тощо, тобто до словесного виразу метаправа висуваються ще й певні вимоги. До них належать чіткість, однозначність, природність, логічність, послідовність, спадковість за- 
стосовуваних понять, які мають важливе значення для правозастосовної практики [12, с. 9]. Так, чіткість юридичного терміну виражає точність відображуваного юридичного факту; однозначність - наявність лише одного його змістового наповнення; природність - дійсне існування певного поняття та відповідність його справжній сутності; логічність - юридично правильне вираження терміну; послідовність - розвиток правових тенденцій з метою досягнення правової визначеності, системності права та зниження його колізійності; спадковість - дотримання правової традиції, зокрема зосередження на основному призначенні права, що може бути реалізоване шляхом застосування метаправа зокрема. Також важливими вимогами до застосування метаправа $\epsilon$ загальновизнаність, стабільність та доступність [1, с. 217218], які полягають у належному сприйнятті певною спільнотою конкретної юридичної термінології, тривалості їі застосування та можливості правильно розуміти їі зміст відповідно. Ще одна вимога відсутність емоційного забарвлення, що виражає об'єктивне ставлення до терміну без вказівки на його позитивний чи негативний зміст, адже він має відображати лише лаконічну сутність певного юридичного факту, пов'язана із стилістичною нейтральністю, тобто універсальністю формулювання терміну. Крім того, певні вимоги до термінології законопроектів передбачені Методичними рекомендаціями щодо розроблення проектів законів та дотримання вимог нормопроектної техніки [13], які все ще використовуються, однак, зважаючи на застарілу редакцію та відсутність внесення змін та доповнень 3 урахуванням нових тенденцій розвитку суспільства та його потреб, деякі положення втратили свою актуальність. Тому на сьогодні все більшого значення в Україні набуває питання прийняття нового закону, який би вирішив дану проблему. Загалом, завдяки існуванню певних вимог забезпечуються формальна визначеність нормативно-правового акту та юридичного документу, а також ефективність метаправа, яка перевіряється застосуванням правової експертизи.

Однією 3 особливостей метаправа також $є$ його визнання як «закономірного, завершального циклу правового розвитку; як остаточної фази еволюції права» [14, с. 47; 15]. Такі міркування пояснюються впливом глобалізації на розвиток самого права, що виявляється, перш за все, у його змісті, одним з виразників якого i $\epsilon$ метаправо. Модернізація метаправа виступає важливою складовою удосконалення законодавства і юридичної практики, правового регулювання загалом, а отже, і суспільного розвитку зокрема, що свідчитиме про ефективну реалізацію функцій права завдяки інноваційності метаправа як елементу юридичної техніки.

Тлумачення і розуміння метаправа здійснюється шляхом герменевтико-феноменологічного аналізу, в основі якого лежить тропологічна теорія дискурсу, що $є$ «інструментом аналізу й осмислення фактів, образів, понять і зв'язків між ними» [16, c. 86]. Такий спосіб тлумачення метаправа включає наративний та дискурсивний аспекти, що полягають у з'ясуванні змісту юридичного терміну залежно від особливостей його авторського формулювання та його взаємодії з іншими мовними та 
правовими факторами відповідно, що дозволяє найбільш точно з'ясувати зміст конкретного терміну.

Що ж до значення метаправа, то на основі аналізу його сутності та особливостей можливо обгрунтувати його важливість абстрактним відображенням дійсності, наданням нормативно-правовим актам та юридичним документам змістовної упорядкованості та формальної визначеності, а також вираженням сутності права та впливом на його гнучкість. Основне ж значення метаправа виражається в забезпеченні ефективності механізму правового регулювання.

Так, відображення юридичним терміном «узагальненого найменування юридичного поняття вважається досконалим лише в тому випадку, якщо він з оптимальною точністю відображає його цілісний зміст, його логічну структуру та істотні ознаки» $[17$, с. 182], тобто у даному випадку значення метаправа полягає в об'єктивному відтворенні дійсності. Точність такої абстрактної реальності дозволяє значно підвищити ефективність правозастосування шляхом зменшення вірогідності помилок при тлумаченні юридичного терміну, який відповідає встановленим вимогам.

Крім того, застосування метаправа має значний вплив на результативність дії нормативно-правових актів та інших юридичних документів, адже воно дозволяє упорядкувати їх зміст, зокрема шляхом скорочення їх обсягу за рахунок використання юридичних термінів замість понять, а також метаправо $є$ важливим фактором забезпечення формальної визначеності. Остання зазвичай стосується закріплення норма- тивних приписів у джерелах права, а метаправо виступає інструментом мовно-юридичного вираження змісту цих приписів. За рахунок цього юридична термінологія $€$ одним із найважливіших засобів юридичної мови, що і виражає ії̈ значення.

Із вищезазначеного випливає, що метаправо $\epsilon$ виразником всього права загалом, тобто юридична термінологія «розкриває природу і масштаби права» [15]. Основою сутності права є справедливість, яка об'єктивується в його нормах, текстова формула яких виражена за допомогою метаправа. Одним 3 об'єктів тлумачення правових норм $\epsilon$ юридична термінологія, з'ясування змісту якої сприяє усвідомленню сфер поширення дії права та його значення для суспільства, що і вказує на масштабність права. У свою чергу, найвищою соціальною цінністю $\epsilon$ людина, тому право орієнтоване на захист її прав, свобод та інтересів, що сприяє його лібералізації, зміст якої також залежить від метаправа.

Також «формування метаправового простору через наративний дискурс сприяє забезпеченню гнучкості права» [16, с. 90], яка пов'язана не лише з його модернізацією, введенням нових правових положень, а й з особливостями тлумачення, інтертекстуальності тощо. Так, зміст певного юридичного терміну в умовах розвитку суспільства може частково чи повністю змінюватися, а взаємодія з іншими нормативно-правовими актами та юридичними документами також має вплив на його застосування. Розвиток метаправа має значення і для права, зумовлюючи його гнучкість відповідно до потреб та інтересів суспільства. 
Загальне ж значення метаправа полягає в ефективному функціонуванні механізму правового регулювання. Вірне застосування юридичної термінології $\epsilon$ важливим компонентом якості закону, що є запорукою його належної реалізації, адже закон один із засобів правового регулювання. До того ж, метаправо $\epsilon$ інструментом формулювання мети правового регулювання, наявність якої зумовлює можливість співвіднести її 3 результатом, що $\epsilon$ показником ефективості правового регулювання. Для досягнення суспільно значущої, поставленої правом мети визначаються предмет і метод конкретного правового регулювання, а також його засоби, юридична ж термінологія дозволяє закріпити їх в нормативно-правових актах, а тому метаправо $є$ певним інструментом механізму правового регулювання.

Висновки. Отже, із аналізу вищевикладеного випливає, що метаправо - комплексна юридиколінгвістична категорія, яка включає в себе не тільки юридичну термінологію, а й правила і механізми її застосування, експертизи, тлумачення тощо, що зумовлює можливість розуміння досліджуваного явища як техніко-юридичного засобу, який характеризується інноваційністю, нерозривним зв'язком 3 правовою дійсністю, універсальністю та абстрактністю тлумачення, розуміння та реалізації. Слід погодитися з думками науковців, що розуміння цього явища не обмежується вищезазначеним; навпаки, воно розкривається у декількох підходах, які висвітлюють його як складову юридичної техніки; правовий засіб, інтегрований з інформаційними технологіями; елемент правової системи; всепланетне право та міжцивілізаційне явище, кожен 3 яких акцентує увагу на певних особливостях метаправа.

До особливостей метаправа належать обумовленість його розвитку впливом науково-юридичного прогресу, забезпечення необхідної конфігурації загальнообов'язкових вимог, спричинення шляхом поєднання глобалізаційних та модернізаційних процесів сприйняття цієї категорії як вищого рівня правового розвитку, а також тропологічний спосіб тлумачення юридичної термінології на основі наративного та дискурсивного аспектів. Фрагментарні аспекти значення метаправа, що виявляються в абстрактному відображенні дійсності, наданні нормативноправовим актам та іншим юридичним документам змістовної упорядкованості та формальної визначеності, вираженні сутності права та впливі на його сутність, інтегруються в забезпечення ефективності механізму правого регулювання.

Перспективи подальших наукових розвідок обраної теми знаходяться у площині гострої необхідності підвищення якості закону та його ефективності, що, в тому числі, здійснюється через аналіз категорії метаправа. Причому найбільш доцільно проводити такі дослідження, звертаючись як до правової доктрини, так і до нормативних засад життєдіяльності суспільства.

\section{Список використаних джерел}

1. Козюбра М. І., Погребняк С. П., Цельєв О. В., Матвєєва Ю. І. Загальна теорія права: підручник. За заг. ред. М. І. Козюбри. Київ : Ваіте, 2015. 392 с. 
2. Мінченко О.В. Роль семіотики в процесах утворення та реалізації права. Актуальні проблеми вітчизняної юриспруденції. 2018. № 3. С. 32-35.

3. Балинська О. М. Семіотика права: філософсько-правовий методологічний підхід і науковий напрям. Університетські наукові записки. 2014. № 2 (50). С. 35-42.

4. Голоскоков Л. Будущие сетевые технологии права. URL: http://irex.ru/ press/pub/polemika/08/gol/index.html (дата звернення: 16.02.2020).

5. Аюпова З. К., Кусаинов Д. У. Современные тенденции глобализации и ее роль в интеграции права. Вестник КарГУ. Юриспруденщия. 2015. URL: https://articlekz.com/ article/11835 (дата звернення: 16.02.2020).

6. Сливка С. С. Канонічне право: природний та метакорпоративний порівняльні аспекти: Відкрита лекція. Київ-Львів : ЗУКЦ, 2012. Серія науково-методичних видань «Академія порівняльного правознавства». Вип. 26. 16 с.

7. Кучук А. М. Юридична термінологія у світлі правового поліцентризму (теоретико-правовий аспект). Порівняльно-аналітичне право. 2014. № 5. С. 38-40.

8. Самигуллин В.К. Метаправо как нетривиальное исследовательское направление. Проблемы востоковедения. 2013. № 4 (62). С. 74-78.

9. Haley A. G. Space Law and Government. New York : Appleton - Century - Crofts. 1963. 584 p.

10. Крейн І. Цивілізаційні розломи і зіткнення цивілізацій: метапідхід. Права людини в Україні. Інформаційний портал Харківської правозахисної групи. URL: http://khpg.org/index.php?id=1519500852 (дата звернення: 16.02.2020).

11. Волошенюк О.В. Метаправо, або деякі проблеми сучасної юридичної термінології. Форум права. 2016. № 3. С. 25-30.

12. Горобець Н. О. Проблеми використання юридичної термінології в законодавстві України. Науковий вісник Херсонського державного університету. Серія «Юридичні науки». 2016. Вип. 1. Т. 1. С. 7-10.

13. Методичні рекомендації щодо розроблення проектів законів та дотримання вимог нормопроектної техніки: рекомендації Міністерства юстиції України від 21 листопада 2000 року, № 41. URL: https://zakon.rada.gov.ua/laws/show/v0041323-00 (дата звернення: 16.02.2020).

14. Кравченко В. Ю. Вплив процесу глобалізації на право. Правова освіта та правова наука в умовах сучасних трансформаційних процесів. матер. Всеукр. наук.практ. конф. (Запоріжжя, 11 листопада 2017 р.). Запоріжжя : ЗНУ, 2017. С. 46-48.

15. Ударцев С. Ф. О некоторых тенденциях глобальной эволюции государства и права. Караганда : Болашак-Баспа, 2004. 52 с.

16. Мелякова Ю. В. Метод деконструкции в наррации и интерпретации права. Вісник Національного університету «Юридична академія України імені Ярослава Мудрого». 2017. № 1 (32). С. 85-92.

\section{References}

Koziubra, M. I., Pohrebniak, S. P., Tseliev, O. V., Matvieieva, Yu. I. (2015). Zahalna teoriia prava: pidruchnyk. Kyiv: Vaite [in Ukrainian].

Minchenko, O.V. (2018). Rol semiotyky v protsesakh utvorennia ta realizatsii prava. Aktualni problemy vitchyznianoi yurysprudentsii, 3, 32-35 [in Ukrainian].

Balynska, O. M. (2014). Semiotyka prava: filosofsko-pravovyi metodolohichnyi pidhid I naukovyi napriam. Universytetski naukovi zapysky, 2 (50), 35-42 [in Ukrainian].

Holoskokov, L. (2020). Budushchie setevye tekhnologii prava. URL: http://irex.ru/press/pub/polemika/08/gol/index.html (data zvernennia: 16.02.2020) [in Russian]. 
Aiupova, Z. K., Kusainov, D. U. (2015). Sovremennye tendentsii globalizatsii I yee rol v integratsii prava. Vestnik KarGU. Yurisprudentsiia. URL: https://articlekz.com/article/11835 (data zvernennia: 16.02.2020) [in Russian].

Slyvka, S. S. (2012). Kanonichne pravo: pryrodnyi ta metakorporatyvnyi porivnialni aspekty: vidkryta lektsiia. Kyiv-Lviv: ZUKTS. Seriia naukovo-metodychnykh vydan «Akademiia porivnialnoho pravoznavstva». Vyp. 26 [in Ukrainian].

Kuchuk, A. M. (2014). Yurydychna terminolohiia u svitli pravovoho politsentryzmu (teoretyko-pravovyi aspekt). Porivnialno-analitychne pravo, 5, 38-40 [in Ukrainian].

Samigullin, V. K. (2013). Metapravo kak netrivialnoe issledovatelskoe napravlenie. Problemy vostokovedeniia, 4 (62), 74-78 [in Ukrainian].

Haley, A.G. (1963). Space Law and Government. New York: Appleton - Century Crofts. 1963.584 p.

Krein, I. Tsyvilizatsiini rozlomy I zitknennia tsyvilizatsii: metapidkhid. Prava liudyny $v$ Ukraini. Informatsiinyi portal Kharkivskoi pravozakhysnoi hrupy. 24.02.2018. URL: http://khpg.org/index.php?id=1519500852 (data zvernennia: 16.02.2020) [in Ukrainian].

Volosheniuk, O. V. (2016). Metapravo, abo deiaki problem suchasnoi yurydychnoi terminolohii. Forum prava, 3, 25-30 [in Ukrainian].

Horobets, N. O. (2016). Problemy vukorystannia yurydychnoi terminolohii v zakonodavstvi Ukrainy. Naukovyi visnyk Khersonskoho derzhavnoho universytetu. Seriia «Yurydychni nauky», 1, 1, 7-10 [in Ukrainian].

Kravchenko, V.Yu. (2017). Vplyv protsesu hlobalizatsii na pravo. Pravova osvita ta pravova nauka $v$ umovakh suchasnykh transformatsiinykh protsesiv. mater. Vseukr. nauk.prakt. konf. (Zaporizhzhia, 11 lystopada 2017 r.). Zaporizhzhia: ZNU, 46-48 [in Ukrainian].

Udartsev, S. F. (2004). O nekotorykh tendentsiiakh globalnoy evoliutsii gosudarstva $i$ prava. Karaganda: Bolashak-Baspa [in Russian].

Meliakova, Yu.V. (2017). Metod dekonstruktsii i interpretatsii prava. Visnyk Natsionalnoho universytetu «Yurydychna akademiia Ukrainy imeni Yaroslava Mudroho», 1 (32), 85-92 [in Ukrainian].

\section{Drach, Student of the Vasyl' Stus Donetsk National University ORCID: 0000-0002-9111-2694}

\section{The metalaw: problems of understanding and meaning for legal science and practice}

The work investigates the problems of understanding and meaning of the metalaw for legal science and practice. The metalaw is determined as a complex legal and linguistic category, which can be understood as a component of the legal technique, an integrated with information technology legal remedy, an element of the legal system, a planetary law and an inter-civilization phenomenon.

It is suggested to include in concept «metalaw» not only legal terminology, but also rules and mechanisms of its applying, expertise, interpretation etcetera, which allows us to expand essence of researched legal phenomenon.

The features of correlation of the metalaw with the legal technique and the semiotics of law are exposed. The metalaw is characterized as a part of the legal rulemaking technique and a main «mechanism» of the legal technique. The semiotics of law is defined as a structural element and remedy of formation of legal terminology. 
It is also revealed, that essence of the metalaw is expressed with its features, which include scientific nature, certain requirements of its expression, its understanding as the highest level of the legal development and tropological interpretation.

In the work meaning of the metalaw is also comprehended, concerning abstract reflection of reality, provision of legal acts and legal documents of substantive order and formal certainty, expression of essence of law and influence on its flexibility, which can be generalized with providing of efficiency of mechanism of legal regulation. It is possible due to fixing with the legal terminology of subject and method of certain legal regulation in legal acts, which allows us to understand the metalaw as a certain instrument of the mechanism of legal regulation.

As a result of research it seems possible to define the metalaw as an element of the legal technique which consists in legally-terminological display of legal reality with using of language means, which is characterised with special mechanisms of implementation, which are conditioned with needs of society on certain stage of its development and other features of its essence, which is an indicator of certain legal system at the same time and functionates within the certain geographically-time area.

Keywords: metalaw; legal technique; legal speech; legal act; legal documen; legal regulation. 